Md. Rezaul Karim Khan ${ }^{1}$, Abu Nasir Rizvi ${ }^{1}$, Md. Ahsan Habib ${ }^{2}$, Md. Razibul Alam³ ${ }^{3}$ Muhammad Khalid Hasan $^{4}$, Ajmiree Mamun ${ }^{5}$, Rashedul Islam ${ }^{6}$

Bangladesh Journal of Neuroscience 2016; Vol. 32 (2): 74-84

\title{
Frequency and Risk Factors of Pneumonia and Urinary Tract Infection during Hospitalization in Acute Stroke Patients.
}

\author{
SHAHED AHMAD ${ }^{1}$, MATIUR RAHMAN ${ }^{2}$, MOSTAFA HOSEN $^{3}$, ABUL KALAM, $^{2}$ \\ MOHAMMED SHOAB ${ }^{3}$, MD RAFIQUL ISLAM ${ }^{4}$
}

\begin{abstract}
:
Background: Acute stroke Patients are at risk of developing a wide range of complications. Among these medical complications the most common are infections, including pneumonia and urinary tract infection (UTI). This study was designed to see the frequency and risk factors of pneumonia and UTI after acute stroke in hospitalized patients.

Methods : This prospective observational study was done in the Department of Neurology and Department of Medicine, Sylhet M.A.G Osmani Medical College Hospital, from May 2014 to November 2014. After hospitalization, a total number of 80 acute stroke patients were enrolled in this study. All patients of both sexes, presented with acute stroke, were confirmed by CT scan of head; vascular risk factors were recorded and relevant investigations were done.

Results: Among the study subjects Urinary tract infection was found in 23 (28.8\%) patients. Statistically significant risk factors for UTI were : > 65 years age $(O R=2.926$; $95 \%$ of $C l=1.044-8.202 ; p=0.037)$. Female gender $(O R=0.327 ; 95 \%$ of $C l=0.120-0.889$; $p=0.026)$, diabetes $(O R=2.015 ; 95 \%$ of $C l=1.019-7.780 ; p=0.042)$, Severe stroke $(O R=3.331 ; 95 \%$ of $C l=1.217-9.116 ; p=0.017)$, Foley tube catheterization $(O R=4.229$; 95\% of $C l=1.492-11.982 ; p=0.005)$. Pneumonia developed in $17(21.2 \%)$ patients and no pneumonia in 63 (78.8\%) patients.

Conclusion : UTI and pneumonia are common occurrence after acute stroke during stroke hospitalization. Older age, female gender, diabetes mellitus, severe stroke at presentation and urinary catheterization were found the risk factors of UTI; whereas older age, severe stroke at presentation, nasogastric tube feeding, oropharyngeal suction and difficulty in swallowing were found the risk factors of pneumonia in acute stroke.
\end{abstract}

Keywords : Acute Stroke, Hospitalization, Pneumonia, Urinary tract infection.

Introduction:

Stroke is a crisis in cerebrovascular circulation and central nervous system function with focal neurologic dysfunction ${ }^{1}$. Stroke is the leading cause of major long-term disability in adults and the third leading cause of death after heart disease and cancer ${ }^{2,3}$. The annual incidence of stroke in the community is about 2 per 1,000 population, ${ }^{4}$ and it remains a tremendous public heath burden. Patients who have had an acute stroke are at risk of developing a wide range of complications, including pneumonia, urinary tract infection (UTI), pressure ulcer, falls, venous thromboembolism (VTE), and severe constipation ${ }^{5,-7}$. These complications are important because they may cause death, ${ }^{8-10}$ or can extend the hospital length of stay ${ }^{11-12}$ worsen stroke outcomes, and increase cost of care ${ }^{13}$. Among these medical complications the most common are infections, including pneumonia and urinary tract infection (UTI) ${ }^{14}$.

1. Medical officer, Sylhet MAG Osmani Medical College Hospital

2. Professor of Neurology, Sylhet MAG Osmani Medical College.

3. Assistant Professor of Neurology, Sylhet MAG Osmani Medical College.

4. Professor, Department of Neurology, Bangabandhu Sheikh Mujib Medical University (BSMMU), Dhaka. 
A prospective cohort study $(n=609)$ showed that $59 \%$ of patients had a complication during the mean hospital stay of 37 days ${ }^{14}$ infectious complications were the third most common (after falls and skin breaks) and were predominantly urinary tract infections (UTI) (16\%) and chest infections (12\%). A multicentre study $(n=1386)$ confirmed that amongst infectious complications at 7 days after the acute ischemic stroke onset, pneumonia $(7.4 \%)$ and UTI $(6.3 \%)$ are the most frequent ${ }^{13}$.

Aslanyan et al. ${ }^{15}$ reported that higher baseline National Institute of Health Stroke Scale (NIHSS) and age, male gender, history of diabetes and stroke subtype predicted pneumonia, which occurred in $13.6 \%$ of patients. Female gender and higher baseline NIHSS and age predicted UTI, which occurred in $17.2 \%$ of patients. Pneumonia was associated with poor outcome by mortality (hazard ratio, 2.2; 95\% confidence interval, 1.53.3), Barthel index (<60) (odds ratio, 3.8; 2.2-6.7), NIHSS (4.9; 1.7-14) and Rankin scale (e"2) (3.4; 1.4-8.3). UTI was associated with Barthel index (1.9; 1.2-2.9), NIHSS (2.2; 1.2-4.0) and Rankin scale $(3.1 ; 1.6-4.9)$. Pneumonia and UTI are independently associated with stroke poor outcome $^{15}$. Therefore, prevention and prompt treatment of these infections in stroke patients might improve outcome ${ }^{16}$.

So, this study is designed to see the Frequency and Risk Factors of pneumonia and UTI after acute stroke.

\section{Materials and Methods:}

It was a hospital based prospective observational study. The sudy was done in the Department of Neurology and Department of Medicine, Sylhet M.A.G Osmani Medical College Hospital, Sylhet. Consecutive admitted acute stroke patients in different Medicine and Neurology units of Sylhet M.A.G Osmani Medical College Hospital, Sylhet, during the study period and fulfilling the inclusion criteria, the study was done from May 2014 to November 2014.

\section{Sampling technique:}

Purposive sampling was employed as sampling technique in this study.

\section{Data Collection Procedure:}

Immediately after admission of a patient of suspected acute stroke, a proper diagnostic work up by taking detail history and clinical examination were done. ACT scan of brain was done to confirm acute stroke. Those, who met the inclusion criteria, were taken as sample

Informed written consent was obtained from the patients or guardians after full explanation of the details of the disease process and purpose of the study.

Past medical and personal history for cigarette smoking, arterial hypertension, diabetes mellitus, and ischaemic heart disease and other associated disease condition were also sought. All the data were recorded in a standard and pretested structured questionnaire.

Stroke severity at admission was determined using the modified National Institutes of Health Stroke Scale ${ }^{17}$ and stroke was classified as mild (score 0-5), moderate (score 6-14) and severe (score 1531) on mNIHSS scale (Appendix-II) ${ }^{18}$.

Pneumonia was diagnosed by the attending clinician and based on the presence of e" 3 of the following variables: fever $\left(>38^{\circ} \mathrm{C}\right)$, productive cough with purulent sputum, abnormal respiratory examination (tachypnea [>22/min], tachycardia, inspiratory crackles, bronchial breathing), abnormal chest radiograph, arterial hypoxemia $\left(\mathrm{PO}_{2}<70 \mathrm{~mm}\right.$ $\mathrm{Hg}$ ), and isolation of a relevant pathogen (positive gram stain and culture) ${ }^{19}$.

UTI was diagnosed if patients presenting with (a) any of the following symptoms: dysuria, frequency, urgency, gross hematuria, or hypogastric pains with positive urine culture. In the absence of a urine culture, the laboratory diagnosis of UTI can be determined by the presence of significant pyuria defined as: (a) 8 or more pus cells $/ \mathrm{mm}^{3}$ of uncentrifuged urine; or (b) 5 or more pus cells/hpf of centrifuged urine ${ }^{20}$. CA-UTI was diagnosed as "the presence of symptoms or signs compatible with UTI with no other identified source of infection along with e" $10^{3}$ colony-forming units (cfu)/mL of e"1 bacterial species" from a catheterized or previously catheterized (d"48 hours) urine sample ${ }^{21}$. 


\section{Results:}

The outcome of the study was as follows: Urinary tract infection was found in $23(28.8 \%)$ patients. Distribution of patients by frequency of urinary tract infection was shown in figure 1.

Pneumonia developed in $17(21.2 \%)$ patients. Distribution of patients by frequency of pneumonia in stroke patients was shown in figure-2.

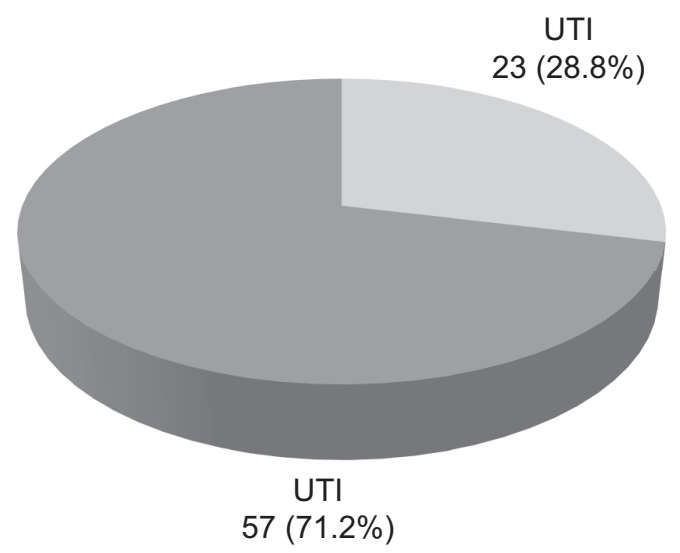

Fig.-1: Distribution of patients by frequency of urinary tract infection $(n=80)$
The mean age of the patients of UTI was significantly higher than that of no UTI $(\mathrm{t}=2.075$; $p=0.041$ ). Relationship between age and development of UTI was shown in table I. The age of the patient 65 years or higher significantly increased the risk of development of UTI compared to those aged under 65 years $(\mathrm{OR}=2.926 ; 95 \%$ of $\left.\mathrm{Cl}=1.044-8.202 ; \mathrm{X}^{2}=4.334 ; \mathrm{p}=0.037\right)$.

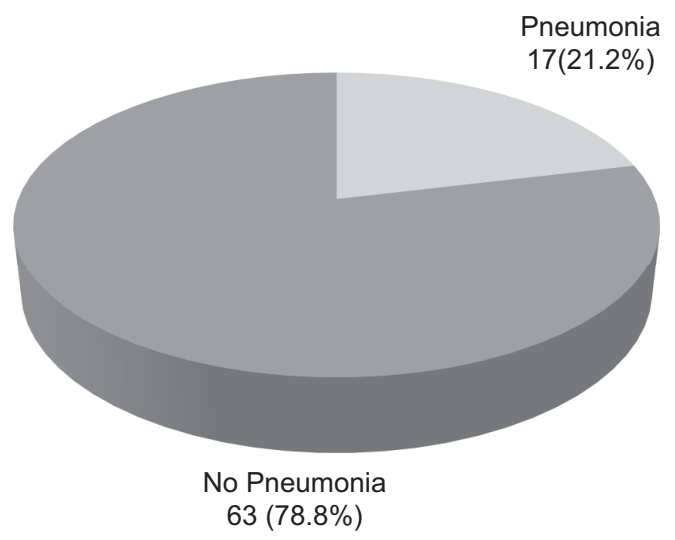

Fig.-2: Distribution of patients by frequency of pneumonia in stroke patients $(n=80)$

Table-I

Relationship between age and development of UTI

\begin{tabular}{|c|c|c|c|c|}
\hline Age & UTI group $(n=23)$ & No UTI group $(n=57)$ & Odds Ratio (95\% of $\mathrm{Cl})$ & $p$ value \\
\hline e"65 years & $16(69.6)$ & $25(43.9)$ & $(1.044-8.202)$ & ${ }^{*} p=0.037$ \\
\hline$<65$ years & $7(30.4)$ & $32(56.1)$ & & \\
\hline Mean \pm SD & $70.96 \pm 19.93$ & $62.53 \pm 14.86$ & & $t_{p}=0.041$ \\
\hline
\end{tabular}

${ }^{*}$ Chi-Square $\left(\chi^{2}\right)$ Test and tunpaired't' test were applied to analyze the data. Figure in the parenthesis indicates corresponding percentage. $\mathrm{Cl}=$ confident interval, $\mathrm{SD}=$ standard deviation. Relationship between gender and development of UTI was shown in table-II. Development of UTI was significantly reduced in male gender compared to that female gender $(\mathrm{OR}=0.327 ; 95 \%$ of $\left.\mathrm{Cl}=0.120-0.889 ; \mathrm{X}^{2}=4.334 ; \mathrm{p}=0.026\right)$.

\section{Table-II}

Relationship between gender and development of UTI

\begin{tabular}{lcccc}
\hline Gender & UTI group $(\mathrm{n}=23)$ & No UTI group $(\mathrm{n}=57)$ & Odds Ratio $(95 \%$ of $\mathrm{Cl})$ & $\mathrm{p}$ value \\
\hline Male & $10(43.5)$ & $40(70.2)$ & $0.327(0.120-0.889)$ & ${ }^{*} \mathrm{p}=0.026$ \\
Female & $13(56.5)$ & $17(29.8)$ & & \\
Total & $23(100.0)$ & $57(100.0)$ & & \\
\hline
\end{tabular}

${ }^{*}$ Chi-Square $\left(\chi^{2}\right)$ Test was applied to analyze the data. Figure in the parenthesis indicates corresponding percentage. $\mathrm{Cl}=$ confident interval, SD=standard deviation. Relationship between type of stroke and development of UTI was shown in table-III. There was no significant relationship between type of stroke and development of UTI $\left(O R=2.234 ; 95 \%\right.$ of $\left.C l=0.450-11.098 ; X^{2}=1.008 ; p=0.316\right)$. 
Table-III

Relationship between type of stroke and development of UTI

\begin{tabular}{lccccr}
\hline Type of stroke & UTI group $(n=23)$ & No UTI group $(n=57)$ & Odds Ratio $(95 \%$ of $\mathrm{Cl})$ & $\mathrm{p}$ value \\
\hline Ischaemic & $21(91.3)$ & $47(82.5)$ & 2.234 & $(0.450-11.098)$ & ${ }^{*} \mathrm{p}=0.316$ \\
Haemorrhagic & $2(8.7)$ & $10(17.5)$ & & & \\
\hline Total & $23(100.0)$ & $57(100.0)$ & & & \\
\hline
\end{tabular}

${ }^{*}$ Chi-Square $\left(\chi^{2}\right)$ Test was applied to analyze the data. Figure in the parenthesis indicates corresponding percentage. $\mathrm{Cl}=\mathrm{confident}$ interval, $\mathrm{SD}=$ standard deviation.

Relationship between common risk factors of stroke and development of UTI shown in table-IV. Risk factors did not have significant role in the development of UTI.

Table-IV

Relationship between risk factors of stroke and development of UTI

\begin{tabular}{lcccc}
\hline $\begin{array}{l}\text { Common risk factors } \\
\text { of stroke }\end{array}$ & $\begin{array}{c}\text { UTI group } \\
(\mathrm{n}=23)\end{array}$ & $\begin{array}{c}\text { No UTI group } \\
(\mathrm{n}=57)\end{array}$ & $\begin{array}{c}\text { Odds Ratio } \\
(95 \% \text { of } \mathrm{Cl})\end{array}$ & $\mathrm{p}$ value \\
\hline Current smoker & $14(60.95)$ & $27(47.4)$ & $1.278(0.645-4.631)$ & $\mathrm{p}=0.274$ \\
Hypertension & $14(60.9)$ & $31(54.4)$ & $1.305(0.487-3.498)$ & $\mathrm{p}=0.597$ \\
Diabetes mellitus & $11(47.8)$ & $14(24.6)$ & $2.015(1.019-7.780)$ & $\mathrm{p}=0.042$ \\
Atrial fibrillation & $4(17.4)$ & $3(5.3)$ & $3.789(0.776-18.501)$ & $\mathrm{p}=0.082$ \\
IHD & $4(17.4)$ & $6(10.5)$ & $1.789(0.455-7.045)$ & $\mathrm{p}=0.401$ \\
Dyslipidaemia & $12(52.2)$ & $29(50.9)$ & $1.053(0.400-2.776)$ & $\mathrm{p}=0.916$ \\
\hline
\end{tabular}

${ }^{*}$ Chi-Square $\left(\chi^{2}\right)$ Test was applied to analyze the data. Figure in the parenthesis indicates corresponding percentage. $\mathrm{Cl}=\mathrm{confident}$ interval, $\mathrm{SD}=$ standard deviation.

Relationship between severity of stroke and development of UTI was shown in table-V. In UTI group, 13 $(56.5 \%)$ patients had severe stroke; while in no UTI group $16(28.1 \%)$ patients had severe stroke. Severe stroke significantly increased the risk of development of UTI (OR=3.331; $95 \%$ of $\mathrm{Cl}=1.217-9.116 ; \mathrm{X}^{2}=5.740$; $\mathrm{p}=0.017)$.

Table-V

Relationship between severity of stroke and development of UTI

\begin{tabular}{|c|c|c|c|c|}
\hline Severity of stroke & $\begin{array}{l}\text { UTI group } \\
\qquad(n=23)\end{array}$ & $\begin{array}{c}\text { No UTI group } \\
(n=57)\end{array}$ & $\begin{array}{l}\text { Odds Ratio } \\
\text { (95\% of } \mathrm{Cl} \text { ) }\end{array}$ & $p$ value \\
\hline Severe & $13(56.5)$ & $16(28.1)$ & $3.331 \quad(1.217-9.116)$ & ${ }^{*} \mathrm{p}=0.017$ \\
\hline Mild to moderate & $10(43.5)$ & 41 (71.9) & & \\
\hline Total & $23(100.0)$ & $57(100.0)$ & & \\
\hline
\end{tabular}

${ }^{*}$ Chi-Square $\left(\chi^{2}\right)$ Test was applied to analyze the data. Figure in the parenthesis indicates corresponding percentage. $\mathrm{Cl}=$ confident interval, SD=standard deviation.

Relationship between catheterization and development of UTI was shown in table-VI. In UTI group, 16 $(69.6 \%)$ patients had Foley tube catheterization; while in no UTI group 20 (35.1\%) patients. Foley tube catheterization significantly increased the risk of development of UTI (OR=4.229; $95 \%$ of $\mathrm{Cl}=1.492-$ 11.982; $\left.X^{2}=7.178 ; p=0.005\right)$. 
Table-VI

Relationship between catheterization and development of UTI

\begin{tabular}{|c|c|c|c|c|}
\hline $\begin{array}{l}\text { Foley tube } \\
\text { catheterization }\end{array}$ & $\begin{array}{l}\text { UTI group } \\
(n=23)\end{array}$ & $\begin{array}{c}\text { No UTI group } \\
(n=57)\end{array}$ & $\begin{array}{l}\text { Odds Ratio } \\
\text { (95\% of } \mathrm{Cl} \text { ) }\end{array}$ & $p$ value \\
\hline Yes & $16(69.6)$ & $20(35.1)$ & $(1.492-11.982)$ & ${ }^{*} p=0.005$ \\
\hline No & $7(30.4)$ & 37 (64.9) & & \\
\hline Total & $23(100.0)$ & 57 (100.0) & & \\
\hline
\end{tabular}

${ }^{*}$ Chi-Square $\left(\chi^{2}\right)$ Test was applied to analyze the data. Figure in the parenthesis indicates corresponding percentage. $\mathrm{Cl}=\mathrm{confident}$ interval, $\mathrm{SD}=$ standard deviation.

Table VII shows the age of the patient 65 years or higher significantly increased the risk of development of pneumonia compared to those aged under 65 years $\left(\mathrm{OR}=4.062 ; 95 \%\right.$ of $\mathrm{Cl}=1.192-13.842 ; \mathrm{X}^{2}=5.496$; $p=0.019$ ).

\section{Table-VII}

Relationship between age and development of pneumonia

\begin{tabular}{lcccc}
\hline Age & $\begin{array}{c}\text { Pneumonia } \\
\text { group }(\mathrm{n}=17)\end{array}$ & $\begin{array}{c}\text { No pneumonia } \\
\text { group }(\mathrm{n}=63)\end{array}$ & $\begin{array}{c}\text { Odds Ratio } \\
(95 \% \text { of } \mathrm{Cl})\end{array}$ & $\mathrm{p}$ value \\
\hline$\geq 65$ years & $13(76.5)$ & $28(44.4)$ & $4.062(1.192-13.842)$ & ${ }^{*} \mathrm{p}=0.019$ \\
$<65$ years & $4(23.5)$ & $32(55.6)$ & & \\
Mean \pm SD & $71.82 \pm 13.33$ & $63.10 \pm 13.41$ & & ${ }^{\dagger} \mathrm{p}=0.020$ \\
\hline
\end{tabular}

${ }^{*}$ Chi-Square $\left(\chi^{2}\right)$ Test and tunpaired ' $t$ ' test were applied to analyze the data. Figure in the parenthesis indicates corresponding percentage. $\mathrm{Cl}=$ confident interval, $\mathrm{SD}=$ standard deviation.

Relationship between gender and development of pneumonia was shown in table-VIII. In pneumonia group, $13(76.5 \%)$ patients were male; while in no pneumonia $37(58.7 \%)$ patients were male. There was no gender variation in the development of pneumonia $\left(\mathrm{OR}=2.284 ; 95 \%\right.$ of $\mathrm{Cl}=0.669-7.796 ; \mathrm{X}^{2}=1.798$; $p=0.180)$.

\section{Table-VIII}

Relationship between gender and development of pneumonia

\begin{tabular}{lcccc}
\hline Gender & $\begin{array}{c}\text { Pneumonia group } \\
(\mathrm{n}=17)\end{array}$ & $\begin{array}{c}\text { No pneumonia group } \\
(\mathrm{n}=63)\end{array}$ & $\begin{array}{c}\text { Odds Ratio } \\
(95 \% \text { of } \mathrm{Cl})\end{array}$ & $\mathrm{p}$ value \\
\hline Male & $13(76.5)$ & $37(58.7)$ & $2.284(0.669-7.796)$ & $\mathrm{p}=0.180$ \\
Female & $4(23.5)$ & $26(41.3)$ & & \\
\hline Total & $17(100.0)$ & $63(100.0)$ & & \\
\hline
\end{tabular}

${ }^{*}$ Chi-Square $\left(\chi^{2}\right)$ Test was applied to analyze the data. Figure in the parenthesis indicates corresponding percentage. $\mathrm{Cl}=$ confident interval, $\mathrm{SD}=$ standard deviation.

Relationship between type of stroke and development of pneumonia shown in Table-IX.There was no significant relationship between type of stroke and development of pneumonia $(O R=1.415 ; 95 \%$ of $\left.\mathrm{Cl}=0.279-7.171 ; \mathrm{X}^{2}=0.177 ; \mathrm{p}=0.674\right)$. 
Table-IX

Relationship between type of stroke and development of pneumonia

\begin{tabular}{|c|c|c|c|c|}
\hline Type of stroke & $\begin{array}{c}\text { Pneumonia group } \\
(\mathrm{n}=17)\end{array}$ & $\begin{array}{c}\text { No pneumonia group } \\
(\mathrm{n}=63)\end{array}$ & $\begin{array}{l}\text { Odds Ratio } \\
\text { (95\% of } \mathrm{Cl})\end{array}$ & $\mathrm{p}$ value \\
\hline Ischaemic & $15(88.2)$ & $53(84.1)$ & $1.415 \quad(0.279-7.171)$ & $p=0.674$ \\
\hline Haemorrhagic & $2(11.8)$ & $10(15.9)$ & & \\
\hline$\overline{\text { Total }}$ & $17(100.0)$ & $63(100.0)$ & & \\
\hline
\end{tabular}

${ }^{*}$ Chi-Square $\left(\chi^{2}\right)$ Test was applied to analyze the data. Figure in the parenthesis indicates corresponding percentage. $\mathrm{Cl}=\mathrm{confident}$ interval, $\mathrm{SD}=$ standard deviation

Relationship between common risk factors of stroke and development of pneumonia was shown in table-X. Rrisk factors did not have significant role in the development of pneumonia.

Table-X

Relationship between risk factors of stroke and development of pneumonia

\begin{tabular}{lcccc}
\hline $\begin{array}{l}\text { Common risk } \\
\text { factors of stroke }\end{array}$ & $\begin{array}{c}\text { Pneumonia group } \\
(\mathrm{n}=17)\end{array}$ & $\begin{array}{c}\text { No pneumonia group } \\
(\mathrm{n}=63)\end{array}$ & $\begin{array}{c}\text { Odds Ratio } \\
(95 \% \text { of } \mathrm{Cl})\end{array}$ & $\mathrm{p}$ value \\
\hline Smoker & $13(76.5)$ & $28(44.4)$ & $1.22(0.41-3.61)$ & $\mathrm{p}=0.721$ \\
Hypertension & $11(64.7)$ & $34(54.0)$ & $1.56(0.51-4.75)$ & $\mathrm{p}=0.428$ \\
Diabetes mellitus & $7(42.2)$ & $18(28.6)$ & $1.75(0.58-5.31)$ & $\mathrm{p}=0.320$ \\
Atrial fibrillation & $3(17.6)$ & $4(6.3)$ & $3.16(0.63-15.75)$ & $\mathrm{p}=0.143$ \\
IHD & $3(17.6)$ & $7(11.1)$ & $1.71(0.39-7.48)$ & $\mathrm{p}=0.470$ \\
Dyslipidaemia & $11(64.7)$ & $30(47.6)$ & $2.02(0.66-6.12)$ & $\mathrm{p}=0.211$ \\
\hline
\end{tabular}

${ }^{*}$ Chi-Square $\left(\chi^{2}\right)$ Test was applied to analyze the data. Figure in the parenthesis indicates corresponding percentage. $\mathrm{Cl}=\mathrm{confident}$ interval, $\mathrm{SD}=$ standard deviation

Relationship between severity of stroke and development of pneumonia was shown in table-XI. Severe stroke significantly increased the risk of development of pneumonia (OR=3.308; $95 \%$ of $\mathrm{Cl}=1.095-9.995$; $\left.\mathrm{X}^{2}=4.760 ; \mathrm{p}=0.017\right)$.

Table-XI

Relationship between severity of stroke and development of pneumonia

\begin{tabular}{|c|c|c|c|c|}
\hline Severity of stroke & $\begin{array}{c}\text { Pneumonia group } \\
(\mathrm{n}=17)\end{array}$ & $\begin{array}{l}\text { No pneumonia group } \\
(n=63)\end{array}$ & $\begin{array}{l}\text { Odds Ratio } \\
\text { (95\% of } \mathrm{Cl} \text { ) }\end{array}$ & $p$ value \\
\hline Severe & $10(58.8)$ & $19(30.2)$ & $3.308 \quad(1.095-9.995)$ & ${ }^{*} p=0.029$ \\
\hline Mild to moderate & $7(41.2)$ & $44(69.8)$ & & \\
\hline Total & $17(100.0)$ & $63(100.0)$ & & \\
\hline
\end{tabular}

${ }^{*}$ Chi-Square $\left(\chi^{2}\right)$ Test was applied to analyze the data. Figure in the parenthesis indicates corresponding percentage. $\mathrm{Cl}=\mathrm{confident}$ interval, $\mathrm{SD}=$ standard deviation

Relationship between nasogastric (NG) tube feeding and development of pneumonia was shown in table-XII. Nasogastric tube feeding significantly increased the risk of development of pneumonia $\left(\mathrm{OR}=4.062 ; 95 \%\right.$ of $\left.\mathrm{Cl}=1.192-13.842 ; \mathrm{X}^{2}=5.496 ; \mathrm{p}=0.019\right)$. 


\section{Table-XII}

Relationship between nasogastric tube feeding and development of pneumonia

\begin{tabular}{|c|c|c|c|c|}
\hline NG tube feeding & $\begin{array}{l}\text { Pneumonia group } \\
(\mathrm{n}=17)\end{array}$ & $\begin{array}{c}\text { No pneumonia group } \\
(n=63)\end{array}$ & $\begin{array}{l}\text { Odds Ratio } \\
\text { (95\% of } \mathrm{Cl} \text { ) }\end{array}$ & $p$ value \\
\hline$\overline{\text { Yes }}$ & $13(76.5)$ & $28(44.4)$ & $4.062 \quad(1.192-13.842)$ & $p=0.019$ \\
\hline No & $4(23.5)$ & $35(55.6)$ & & \\
\hline$\overline{\text { Total }}$ & $17(100.0)$ & $63(100.0)$ & & \\
\hline
\end{tabular}

${ }^{*}$ Chi-Square $\left(\chi^{2}\right)$ Test was applied to analyze the data. Figure in the parenthesis indicates corresponding percentage. $\mathrm{Cl}=\mathrm{confident}$ interval, $\mathrm{SD}=$ standard deviation

Relationship between oropharyngeal suction and development of pneumonia was shown in table-XIII. Oropharyngeal suction significantly increased the risk of development of pneumonia (OR=3.778; $95 \%$ of $\left.\mathrm{Cl}=1.207-11.827 ; \mathrm{X}^{2}=5.602 ; \mathrm{p}=0.018\right)$.

Table-XIII

Relationship between oropharyngeal suction and development of pneumonia

\begin{tabular}{|c|c|c|c|c|c|}
\hline $\begin{array}{l}\text { Oropharyngeal } \\
\text { suction }\end{array}$ & $\begin{array}{l}\text { Pneumonia group } \\
(\mathrm{n}=17)\end{array}$ & $\begin{array}{l}\text { No pneumonia group } \\
(\mathrm{n}=63)\end{array}$ & & $\begin{array}{l}\text { dds Ratio } \\
95 \% \text { of } \mathrm{Cl} \text { ) }\end{array}$ & $p$ value \\
\hline Yes & $8(47.1)$ & $12(19.0)$ & 3.778 & $(1.207-11.827)$ & $p=0.018$ \\
\hline No & $9(52.9)$ & $51(81.0)$ & & & \\
\hline Total & $17(100.0)$ & $63(100.0)$ & & & \\
\hline
\end{tabular}

${ }^{*}$ Chi-Square $\left(\chi^{2}\right)$ Test was applied to analyze the data. Figure in the parenthesis indicates corresponding percentage. $\mathrm{Cl}=\mathrm{confident}$ interval, $\mathrm{SD}=$ standard deviation

Relationship between difficulty in swallowing and development of pneumonia was shown in table$X I V$,difficulty in swallowing significantly increased the risk of development of pneumonia $(\mathrm{OR}=3.942$; $95 \%$ of $\left.\mathrm{Cl}=1.277-12.170 ; \mathrm{X}^{2}=6.128 ; \mathrm{p}=0.013\right)$.

Table-XIV

Relationship between difficulty in swallowing suction and development of pneumonia

\begin{tabular}{|c|c|c|c|c|}
\hline $\begin{array}{l}\text { Difficulty } \\
\text { in swallowing }\end{array}$ & $\begin{array}{l}\text { Pneumonia group } \\
(n=17)\end{array}$ & $\begin{array}{l}\text { No pneumonia group } \\
\qquad(\mathrm{n}=63)\end{array}$ & $\begin{array}{l}\text { Odds Ratio } \\
(95 \% \text { of } \mathrm{Cl})\end{array}$ & $\mathrm{p}$ value \\
\hline Yes & $11(64.7)$ & $20(31.7)$ & $3.942 \quad(1.277-12.170)$ & $p=0.013$ \\
\hline No & $6(35.3)$ & $43(68.3)$ & & \\
\hline Total & $17(100.0)$ & $63(100.0)$ & & \\
\hline
\end{tabular}

${ }^{*}$ Chi-Square $\left(\chi^{2}\right)$ Test was applied to analyze the data. Figure in the parenthesis indicates corresponding percentage. $\mathrm{Cl}=\mathrm{confident}$ interval, $\mathrm{SD}=$ standard deviation

Discussion :

A total 80 patients with acute stroke of first attack were selected according to inclusion and exclusion criteria. Urinary tract infection (UTI) was found in $23(28.8 \%)$ patients . This result was supported by Roth et al. ${ }^{22}$ and Ersoz et al. ${ }^{23}$ Roth et al. ${ }^{22}$ found that frequency of UTI among their stroke patients was $30.5 \%$ and Ersoz et al. ${ }^{23}$ observed the frequency of symptomatic UTI in $27.3 \%$ of their stroke patients.

In the present study, the mean age of the patients of UTI was significantly higher than that of no UTI $(t=2.075 ; p=0.041)$. This result was correlated with the study of Stott et al. ${ }^{16}$ that the mean age of the patients with UTI was significantly higher than that of with no UTI [75.7 (SD 10.5) vs 66.4 (SD 14.0) 
years; $p<0.001)]$. But Chen et al. ${ }^{24}$ did not find significant difference between the patient of UTI and that of no UTI [73.5 (SD 6.3) vs 73.2 (SD 5.8); $p>0.05]$.

In the current study,the age of the patient 65 years or higher significantly increased the risk of development of UTI compared to those aged under 65 years $(\mathrm{OR}=2.926$; $95 \%$ of $\mathrm{Cl}=1.044-8.202$; $\mathrm{p}=0.037$ ). This results was nearly correlated with the study of Ovbiagele et al. ${ }^{25}$ that older aged patients with stroke significantly increased the risk of development of UTI (OR=1.20; $95 \%$ of $\mathrm{Cl}=1.01$ 1.43; $p=00.04)$. Ersoz et al. ${ }^{23}$ that $19.6 \%$ patients were aged under 65 years and $35.2 \%$ patients aged 65 years or higher developed UTI $(p=0.067)$.

This study showed development of UTI was significantly reduced in male gender compared to that female gender $(\mathrm{OR}=0.327 ; 95 \%$ of $\mathrm{Cl}=0.120$ $0.889 ; p=0.026$ ). This result was in line with the study of Ovbiagele et al. ${ }^{25}$ that male patients with stroke decreased the risk of UTI (OR=0.50; 95\% of $\mathrm{Cl}=0.33,0.74 ; \mathrm{p}=0.0006)$. But this result was different from the study of Chen et al. ${ }^{24}$ and Stott et al. ${ }^{16}$ Chen et al. ${ }^{24}$ found that $43.3 \%$ of UTI patients were male and $50.3 \%$ of patients with no UTI were male ( $p>0.05)$. Stott et al. ${ }^{16}$ reported that $41.5 \%$ of UTI patients were male and $51.3 \%$ of patients were male in patients with no UTI $(p=0.149)$.

There was no significant relationship between type of stroke and development of UTI (OR=2.234; 95\% of $\mathrm{Cl}=0.450-11.098 ; \mathrm{p}=0.316)$. Similar result was observed in the study of Stott et al. ${ }^{16}$ that type of stroke did not differ between UTI group and nonUTI group $(p=0.847)$.

The difference between diabetic and non-diabetic was statistically significant (OR=2.015; $95 \%$ of $\mathrm{Cl}=1.019-7.780 ; \mathrm{p}=0.042)$. Chen et al. ${ }^{24}$ and Stott et al. ${ }^{16}$ supported this result.

In the current study 13 (56.5\%) patients had severe stroke in UTI group; while in no UTI group 16 (28.1\%) patients had severe stroke. Severe stroke significantly increased the risk of development of UTI (OR=3.331; $95 \%$ of $\mathrm{Cl}=1.217-9.116 ; \mathrm{p}=0.017)$. In this regards previous studies ${ }^{9,10}$ reported that baseline mNIHSS score was significantly higher in UTI group than that of group with no UTI, ${ }^{9,10}$ and higher baseline NIHSS score was a predictor of UTI in acute stroke patients.

In this study 16 (69.6\%) patients had Foley tube catheterization in UTI group; while in no UTI group $20(35.1 \%)$ patients had Foley tube catheterization. Foley tube catheterization significantly increased the risk of development of UTI (OR=4.229; $95 \%$ of $\mathrm{Cl}=1.492-11.982 ; \mathrm{p}=0.005)$. This result was correlated with the study of Chen et al. ${ }^{24}$ that indwelling catheter in $87.1 \%$ of patients of UTI group and $42.3 \%$ of patients of non-UTI group $(p<0.05)$. Ersoz et al. ${ }^{23}$ also supported this result $(p=0.041)$

In the present study pneumonia developed in 17 $(21.2 \%)$ patients and no pneumonia in $63(78.8 \%)$ patients. This result was supported by other studies ${ }^{24,26}$. Chen et al. ${ }^{24}$ observed the frequency of pneumonia in acute ward was $23.8 \%$ and Sellars et al. ${ }^{26}$ found frequency of pneumonia among their stroke patients was $18.9 \%$. But others reported lower frequency of pneumonia among their stroke patients. Ovbiagele et al. ${ }^{25}$ found pneumonia in $10 \%$ of stroke patients during stroke hospitalization and Aslanyan et al. ${ }^{15}$ found pneumonia in $10.9 \%$ in first week of stroke.

In the current study the mean age of the patients of pneumonia was $71.82 \pm 13.33$ years and that of no pneumonia was $63.10 \pm 13.41$ years. The mean age of the patients of pneumonia was significantly higher than that of no pneumonia $(p=0.020)$. Sellars et al. ${ }^{26}$ supported this result that the mean age of the patients of pneumonia was significantly higher than that of no pneumonia $(75.9 \pm 11.4$ years versus $64.9 \pm 13.9$ years; $p<0.001)$. Ovbiagele et al. ${ }^{25}$ also supported this result. But Chen et al. ${ }^{24}$ did not find significant difference between the mean age of the patients of pneumonia and that of no pneumonia.

In this study $13(76.5 \%)$ patients were aged 65 years or higher in pneumonia group; while in no pneumonia $28(44.4 \%)$ patients were aged 65 years or higher. The age of the patient 65 years or higher significantly increased the risk of development of pneumonia compared to those aged under 65 years $(\mathrm{OR}=4.062 ; 95 \%$ of $\mathrm{Cl}=1.192-13.842$; $p=0.019$ ). in this regards Ovbiagele et al ${ }^{25}$ found 
that increasing age per decade increased the risk of development of pneumonia (OR=1.35; $95 \%$ of $\mathrm{Cl}=1.35$ (1.20-1.52; $p<0.0001)$.

In this study $13(76.5 \%)$ patients were male in pneumonia group; while in no pneumonia 37 $(58.7 \%)$ patients were male. There was no gender variation in the development of pneumonia $(\mathrm{OR}=2.284 ; 95 \%$ of $\mathrm{Cl}=0.669-7.796 ; p=0.180)$. This result was consistent with the study of Ovbiagele et al. ${ }^{25}$ that there was no gender variation in the development of pneumonia (OR=1.11; $95 \%$ of $\mathrm{Cl}=0.66-1.87 ; \mathrm{p}=0.70)$. Chen et al. ${ }^{24}$ and Sellars et al. ${ }^{26}$ also supported this result.

In the current study $15(88.2 \%)$ patients had ischemic and $2(11.8 \%)$ had hemorrhagic stroke in pneumonia group, while in no pneumonia group $53(84.1 \%)$ patients had ischemic and 10 (15.9\%) had hemorrhagic stroke. There was no significant relationship between type of stroke and development of pneumonia (OR=1.415; $95 \%$ of $\mathrm{Cl}=0.279-7.171 ; \mathrm{p}=0.674)$. Chen et al. ${ }^{24}$ supported this result that there was no significant relationship between type of stroke and development of pneumonia.

This study showed that 7 (42.2\%) patients had diabetes mellitus in pneumonia group; while 18 $(28.6 \%)$ patients had diabetes mellitus in no pneumonia group. The difference between the two groups was statistically not significant $(O R=1.75$; $95 \%$ of $\mathrm{Cl}=0.58-5.31 ; \mathrm{p}=0.320$ ). Ovbiagele et al. ${ }^{25}$ supported this result that diabetes mellitus did not increase the risk of development of pneumonia $(\mathrm{OR}=1.56 ; 95 \%$ of $\mathrm{Cl}=0.83-2.95 ; \mathrm{p}=0.17)$. Chen et al. ${ }^{24}$ and Sellars et al. ${ }^{26}$ also supported this result.

This study showed that $13(76.5 \%)$ patients were current smoker in pneumonia group; while 28 (44.4\%) patients were current smoker in no pneumonia group. The difference between the two groups was statistically not significant $(\mathrm{OR}=4.062$; $95 \%$ of $\mathrm{Cl}=0.41-3.61 ; \mathrm{p}=0.721$ ).

In this study severe stroke significantly increased the risk of development of pneumonia ( $\mathrm{OR}=3.308$; $95 \%$ of $\mathrm{Cl}=1.095-9.995 ; \mathrm{p}=0.017)$. In this regards previous study by Sellars et al. ${ }^{26}$ reported that baseline mNIHSS score was significantly higher in pneumonia group than that of no pneumonia group.

Nasogastric tube feeding significantly increased the risk of development of pneumonia (OR=4.062; 95\% of $\mathrm{Cl}=1.192-13.842 ; \mathrm{p}=0.019)$. Chen et al. ${ }^{24}$ supported this result that nasogastric tube feeding was significantly higher in pneumonia group than that of no pneumonia group.

Oropharyngeal suction significantly increased the risk of development of pneumonia ( $\mathrm{OR}=3.778 ; 95 \%$ of $\mathrm{Cl}=1.207-11.827 ; \mathrm{p}=0.018)$. Other available studies did not report the relationship between current smoker and development of UTI. But oropharyngeal suction was required in those patients who had difficulty in swallowing and thereby increases the risk of aspiration.

Difficulty in swallowing significantly increased the risk of development of pneumonia (OR=3.942; 95\% of $\mathrm{Cl}=1.277-12.170 ; p=0.013)$. Sellars et al. ${ }^{26}$ supported this result that dysphagia was significantly higher in pneumonia group than that of no pneumonia group.

\section{Conclusion}

UTI and pneumonia are common occurrence after acute stroke during stroke hospitalization. Older age, female gender, diabetes mellitus, severe stroke at presentation and urinary catheterization are the risk factors of UTI; whereas older age, severe stroke at presentation, nasogastric tube feeding, oropharyngeal suction and difficulty in swallowing are risk factors of pneumonia in acute stroke.

\section{References:}

1. Alajbegovic A, Alajbegovic S. stroke in Diabetic patients in cantonal Hospital Zenica. Med Arh. 2009; 63(4):194-6.

2. Strong K, Mathers C, Bonita R. Preventing stroke: saving lives around the world. Lancet Neurol. 2007; 6:182-7.

3. Bonita R, Beaglehole R. Stroke prevention in poor countries. Time for action. Stroke. 2007; 38:2871-2.

4. Hamidon BB, Raymond AA, Norlinah MI, Jefferelli SB. The predictors of early infection 
after an acute ischaemic stroke. Singapore Med J. 2003; 44:344-6.

5. Govan L, Langhorne P, Weir CJ. Does the prevention of complications explain the survival benefit of organized inpatient (stroke unit) care?: further analysis of a systematic review. Stroke. 2007;38:2536-40.

6. Indredavik B, Rohweder G, Naalsund E, Lydersen S. Medical complications in a comprehensive stroke unit and an early supported discharge service. Stroke. 2008;39:414-20.

7. Ingeman A, Andersen G, Hundborg $\mathrm{HH}$, Svendsen ML, Johnston SP. In-Hospital Medical Complications, Length of Stay, and Mortality Among Stroke Unit Patients. Stroke. 2011;42:3214-8.

8. Bae HJ, Yoon DS, Lee J, Kim BK, Koo JS, Kwon O, et al. In-hospital medical complications and long-term mortality after ischemic stroke. Stroke. 2005;36:2441-5.

9. Cavallini A, Micieli G, Marcheselli S, Quaglini $\mathrm{S}$. Role of monitoring inmanagement of acute ischemic stroke patients. Stroke. 2003;34: 2599-2603.

10. Heuschmann PU, Kolominsky-Rabas PL, Misselwitz B, Hermanek P, Leffmann C, Janzen RW, et al. Predictors of in-hospital mortality and attributable risks of death after ischemic stroke: the German Stroke Registers Study Group. Arch Intern Med. 2004;13:164:1761-8.

11. Saxena SK, Ng TP, Yong D, Fong NP, Gerald $\mathrm{K}$. Total direct cost, length of hospital stay, institutional discharges and their determinants from rehabilitation settings in stroke patients. Acta Neurol Scand. 2006;114: 307-14.

12. Saxena SK, Koh GC, Ng TP, Fong NP, Yong $D$. Determinants of length of stay during poststroke rehabilitation in community hospitals. Singapore Med J. 2007;48:400-7

13. Weimar C, Roth MP, Zillessen G, Glahn J, Wimmer ML, Busse O, et al. German Stroke Date Bank Collaborators. Complications following acute ischemic stroke. Eur Neurol. 2002; 48: 133-40.

14. Davenport RJ, Dennis MS, Wellwood I, Warlow CP. Complications after acute stroke. Stroke. 1996; 27:415-20.

15. Aslanyan S, Weir CJ, Diener HC, Kaste M, Lees KR; GAIN International Steering Committee and Investigators. Pneumonia and urinary tract infection after acute ischaemic stroke: A tertiary analysis of the gain international trial. Eur J Neurol. 2004;11:49_ 53.

16. Stott DJ, Falconer A, Miller H, Tilston JC, Langhorne P. Urinary tract infection after stroke. QJM. 2009; 102: 243-9.

17. Lyden PD, Lu M, Levine SR, Brott TG, Broderick J. NINDS rtPA Stroke Study Group. A modified National Institutes of Health Stroke Scale for use in stroke clinical trials: preliminary reliability and validity. Stroke. 2001;32:1310-7.

18. Govan L, Langhorne P, Weir CJ. Categorizing stroke prognosis using different stroke scales. Stroke. 2009;40(10):3396-9.

19. Mann G, Hankey GJ, Cameron D. Swallowing function after stroke: prognosis and prognostic factors at 6 months. Stroke. 1999;30:744-8.

20. Report of the Task Force on Urinary Tract Infections 1998. The Philippine Clinical Practice Guideline on the Diagnosis and Management of Urinary Tract Infections: A Quick Reference Guide for Clinicians. Phil J Microbiol Infect Dis. 2002; 31(1):27-44

21. Hooton TM, Bradley SF, Cardenas DD, Colgan R, Geerlings SE, Rice JC, et al; Infectious Diseases Society of America. Diagnosis, prevention, and treatment of catheter-associated urinary tract infection in adults: 2009 International Clinical Practice Guidelines from the Infectious Diseases Society of America. Clin Infect Dis. 2010;50:625-63. 
22. Roth E, Lovell L, Harvey R, Heinemann A, Semik $P$ and Diaz $S$. Incidence of and risk factors for medical complications during stroke rehabilitation. Stroke. 2001; 32: 523-9.

23. Ersoz M, Ulusoy $\mathrm{H}$, Oktar MA, Akyuz M. Urinary tract infection and bacteriurua in stroke patients: frequencies, pathogen microorganisms, and risk factors. Am J Phys Med Rehabil. 2007;86:734-41.

24. Chen C-M, Hsu H-C, Tsai W-S, Chang C-H, Chen K-H, Hong C-Z. Infections in acute older stroke in patients undergoing rehabilitation. Am J Phys Med Rehabil. 2012;91:211-9.

25. Ovbiagele B, Hills NK, Saver JL, Johnston SC, For the CASPR Investigators. Incidence \& Risk Factors of pneumonia and urinary tract infection during stroke hospitalization. J Stroke Cerebrovasc Dis. 2006; 15(5): 20913.

26. Sellars C, Bowie L, Bagg J, Sweeney MP, Miller $\mathrm{H}$, Tilston J, et al. Risk Factors for Chest Infection in Acute Stroke: A Prospective Cohort Study. Stroke. 2007; 38:2284-91. 